\title{
WHAT IS WRONG WITH CANADIAN FORESTRY?
}

\author{
By S. Steinhamar
}

\author{
Central Pulpwood Association, Winnipeg, Manitoba.
}

A LL FORESTS on Crown land in Canada are under public ownership $A$ and should be managed for the long term benefit of the nation.

We of the present generation are only custodians of the forests with rights limited by consideration for future generations.

The statement of Forest Policy issued by the Canadian Society of Forest Engineers in 1943 was predicated on this assumption. That statement was, however, inadequate in that it did not define how present malpractices can be overcome and better practices effected.

Current provincial practices are not conducive to sound forestry. Too often provincial forest policies have resulted in exploitation, with maximum revenue the first consideration and expenditures reduced far below a sound minimum. When every year in every province of Canada township after township is logged over, the money collected in dues and royalties actually represents forest capital although the provinces classify it as income to general revenue. It is no more annual income than the money a farmer would obtain from selling his farm.

When the forest services want to undertake expenditures for long term improvements which in private industry would be considered capital investment, the provinces budget it as ordinary expense, and the chances are that if a province in one particular year has heavy outlays for other purposes, the forest service budget will be trimmed down. This sort of accounting practice puts a squeeze on the forest services to the detriment of sound forestry.

Many other factors militate against better forestry in this country. Changes in political administration have brought about changes in personnel, thus detracting from the continuity so urgently needed in forest management. Provincial forestry regulations are largely negative; offering little or no in. ducement to operators to improve forestry practices. The Forest Services are understaffed and underpaid and are not able to compete with industry for personnel. The duties assigned to the Forest Services have become largely administrative while in the interests of the public they should be mainly promotional and educative.

Exploitation with only minor consideration for future forest growth may have been a necessity in the pioneering period in Canada and undoubtedly over-exploitation of the easily accessible areas has helped materially to ease Canadian economy through hard times. The weaknesses of the present practice have now become so apparent, however, that radical remedial action should be undertaken.

Proper forest management demands scientific knowledge and technical skill not of ten found in the rank and file of legislative members, and too rarely possessed by Ministers in charge of the departments involved. 
Undoubtedly the people through their elected legislatures should have a voice in broad policy and should be able to ensure that forests are being managed for their benefit. At the same time, the administration of that policy and the decision as to what proceeds from forest operations should be ploughed back in the interest of long-term policy and how much should be made available as current revenue, should be made by a body not influenced by the immediate fiscal needs of the province concerned.

Properly managed forests should be revenue-producing. They should in fact be run on a business basis, and funds should be available for maintenance and to meet exigencies.

One Provincial Forest Service reports for the five years, 1937 to 1942 :

Total receipts ............\$23,209,517.39

Total Disbursements .......... 12,862,742.03

Excess revenue over all expenditures ...\$10,346,775.36

It would seem doubtful that in this case a proper portion of receipts was ploughed back for improvement and maintenance of the forest and numerous such illustrations could be presented.

In other publiclyowned enterprises management through commissions has proved successful. It is suggested that management of Crown land Forests through provincial commissions would be an improvement over the present system. The benefits would be:

1. Continuity in management.

2. Removal of forestry personnel from political influence.

3. Initiation of proper forest financing through establishment of a "Forest Fund" into which all proceeds from operations would go and from which monies would be available for expenditures on long-term projects. Balances remaining in the "Forest Fund" could be lent to the province at regular rates of interest.

Proper forest management is always concerned with obtaining the big. gest possible long-term cash yield from the forests. The criticism of present provincial forest administration is not that it seeks revenue from the forests but that short-sighted policies adopted for immediate profit sacrifice the higher long-term values which could be obtained. Collection of immediate income from the forests has in all provinces brought about a depletion of forest capital in the more accessible regions, and this procedure sharply conflicts with the long-term interests of the people.

The measures needed to bring about higher long-term cash revenues from the forest are:-

1. Re-investment of the larger part of current proceeds in better protection and road improvements. These two measures would facilitate better utilization and increased growth obtained through silvicultural thinnings and growth obtained through maturing of young stands which otherwise might be destroyed by fire or insect damage. 
2. Encouragement of operations in more remote areas through a graduation in dues charged for stumpage. It is false economy to limit commercial operations to easily accessible areas and to the most profitable species through a too rigid system of dues. While stands in easily accessible areas are being over-exploited, over-mature stands in remote areas deteriorate to the benefit of no one.

The biggest loss of timber, however, is suffered through over-crowding in dense stands. The loss is twofold, viz. retarded growth of trees which eventually will reach maturity and loss of trees which die after having reached commercial size without being harvested.

3. Increase in forestry staff so that no forest officer would have a larger district to supervise than can efficiently be handled. At present very few foresters pretend to know their whole district intimately. A contributing reason for this deplorable state of affairs is lack of proper maps and forest surveys, again caused by lack of personnel and adequate financial appropriations.

Remunerations to all classes of forestry personnel should be on such a scale as to attract the best type of men available. The present situation both in Canada and U.S.A. is that the forest services cannot compete with private industry for men.

4. The Forest Services should be more actively occupied in the promotion of operations and in the establishment of new forest industries than now is the case.

These and other measures all undertaken in the interests of the people could be carried out more efficiently if the Forest Services were under the direction of provincial commissions rather than under the direction of departmental heads subject to change with political change in government.

Present plans for post-war forest management formulated by the Wallace Committee set up by the Federal Government features a National Develop. ment Board which would work with regional committces for short-term and long-term improvements of Canadian forest economy. It is here suggested that one may expect better cooperation between a non-political National Development Board and provincial forest authorities under the direction of departmental heads appointed by any one of several different political regimes.

This last is offered only as a secondary reason for the establishment of Provincial Forest Commissions. The main reason is that forestry is a complex business requiring continuity in planning and administration, business acumen, and freedom from political pressure and economic stringency.

When departmental heads are changed following elections, what guarantee have we of any future stability in forest management?

Only if and when we can get forestry out of current politics and estab. lished on a sound business basis can we expect improvement in Canadian Forestry practices. 